\title{
Pemanfaatan Informasi Geospasial Melalui Interpretasi Citra Digital Penginderaan Jauh untuk Monitoring Perubahan Penggunaan Lahan
}

\author{
Muhammad Rizal Pahleviannur \\ Program Studi Pendidikan Geografi, Universitas Muhammadiyah Surakarta \\ J1. A. Yani Pabelan, Kartasura, Sukoharjo, 57162 \\ Email : a610160022@student.ums.ac.id
}

Dikirim : 7 Mei 2019

Diterima: 19 Mei 2019

\begin{abstract}
Abstrak: Dewasa ini, permasalahan yang terjadi pada setiap wilayah yaitu perubahan penggunaan lahan. Perkembangan fisik yang terjadi di suatu wilayah yang pada awalnya memiliki lahan kosong, sekarang menjadi lahan terbangun, sehingga mengakibatkan luas lahan kosong semakin berkurang. Desa Mudal merupakan salah satu desa yang terletak di Kecamatan Boyolali, Kabupaten Boyolali. Desa Mudal secara ekologis merupakan sebagian besar daerah pertanian. Penelitian ini bertujuan untuk mengidentifikasi jenis-jenis penggunaan lahan dan agihan perubahan penggunaan lahan melalui interpretasi citra digital penginderaan jauh dan survei lapangan. Metode yang digunakan dalam penelitian ini adalah metode penginderaan jauh menggunakan teknik interpretasi citra digital dengan analisis Sistem Informasi Geografis (SIG) terhadap perubahan penggunaan lahan dan observasi lapangan. Analisis data yang dilakukan adalah dengan uji ketelitian interpretasi citra menggunakan perhitungan matriks konfusi yang terdiri dari klasifikasi masing-masing objek dan termasuk salah satu uji untuk mengukur tingkat validitas data. Setelah dilakukan perbandingan antara citra google maps Tahun 2015 dengan survei lapangan Tahun 2018, hasil yang didapat tidak mengalami perubahan secara signifikan.
\end{abstract}

Kata kunci: Interpretasi, Citra, Penginderaan Jauh, Sistem Informasi Geografis, Penggunaan Lahan.

Abstract: Nowadays, the problems that occur in each region are changes in using of land. Physical development that occurs in an area that initially had vacant land, is now a built up land, resulting in diminishing land area. Mudal Village is one of the villages located in Boyolali District, Boyolali Regency. Mudal Village is ecologically a large part of the agricultural area. This study aims to identify the types of land use and distribution of land use through the interpetation of remote sensing digital images and field surveys. The method used in this study is the remote sensing method using digital image interpretation techniques with analysis of Geographic Information Systems $(G I S)$ on changes in land use and field observations. Data analysis was carried out by testing the accuracy of image interpretation using a confusion matrix calculation consisting of the classification consisting of the classification of each object and including one test to measure the validity level of the data. After a comparison between the google maps image in 2015 and the 2018 field survey, the result obtained did not change significantly.

Keywords: Interpretation, Digital Image, Remote Sensing, Geographic Information Systems, Land Use.

\section{Pendahuluan}

Perkembangan fisik suatu wilayah mengakibatkan terjadinya perubahan lahan dari lahan kosong menjadi lahan terbangun, sehingga mengakibatkan luas lahan kosong semakin berkurang dan luas lahan terbangun semakin bertambah. Permasalahan tersebut seiring berjalannya waktu akibat dari bertambahnya jumlah penduduk pada setiap wilayah, pada akhirnya untuk memenuhi kebutuhan mengalami perubahan lahan kosong menjadi sektor yang dibutuhkan masyarakat, seperti industri barang dan jasa atau bahkan permukiman. Lilesand et al dalam Somantri (2016), mendefinisikan penggunaan lahan berhubungan dengan kegiatan 
manusia pada suatu bidang lahan. Penggunaan lahan dapat dikelompokkan dalam dua golongan besar yaitu penggunaan lahan pertanian dan penggunaan lahan non pertanian.

Menurut Djunaedi dalam Utaya (2008), perubahan penggunaan lahan akan terus berlangsung sejalan dengan meningkatnya pertumbuhan ekonomi, sehingga di masa mendatang diperkirakan perubahan penggunaan lahan akan terus terjadi. Lahan merupakan bagian dari permukaan bumi yang bermanfaat bagi kehidupan manusia yang terdiri dari faktor fisik maupun nonfisik (Ritohardoyo, 2013). Aktivitas yang dilakukan oleh manusia mampu mempengaruhi perubahan penggunaan lahan.

Desa Mudal merupakan salah satu desa yang terletak di Kecamatan Boyolali, Kabupaten Boyolali. Desa Mudal terletak empat kilometer di sebelah utara dari pusat Kota Boyolali. Letak geografis Desa Mudal cukup strategis, karena merupakan jalur lintas utama menuju objek pariwisata Umbul Tlatar. Desa Mudal secara ekologis merupakan sebagian besar daerah pertanian. Namun, seiring berjalannya waktu lahan yang terdapat di Desa Mudal berubah menjadi pusat pertumbuhan industri barang dan jasa maupun permukiman.

Pemanfaatan teknologi penginderaan jauh dapat digunakan untuk pemetaan daerah dengan melakukan analisis perubahan penggunaan lahan di suatu wilayah. Peranan penginderaan jauh dapat memudahkan dalam analisis suatu wilayah tanpa berhubungan langsung dengan objek yang akan diteliti. Interpretasi citra dapat dilakukan secara visual maupun digital. Interpretasi visual dilakukan pada citra hardcopy maupun citra yang tertayang pada monitor komputer. Menurut Howard dalam Somantri (2016), interpretasi visual merupakan aktivitas visual untuk mengkaji gambaran muka bumi yang tergambar pada citra dengan tujuan untuk identifikasi objek dan menilai maknanya.

Perubahan penggunaan lahan pada dasarnya tidak dapat dihindarkan dalam pelaksanaan proses pembangunan. Pertumbuhan penduduk yang pesat, serta bertambahnya tuntutan kebutuhan masyarakat terhadap lahan, seringkali mengakibatkan terjadinya benturan kepentingan atas penggunaan lahan, serta mengakibatkan terjadinya ketidaksesuaian antara penggunaan lahan dengan rencana peruntukannya.

Pembangunan yang semakin berkembang ditandai oleh perubahan atau peningkatan dalam pemanfaatan penggunaan lahan. Penyempitan lahan sebagai akibat pemekaran wilayah dapat dilihat dari semakin meningkatnya penggunaan lahan baru. Maka dari itu, penelitian ini dilakukan sesuai dengan karakteristik Desa Mudal dalam permasalahan perubahan penggunaan lahan, sehingga perlu adanya pengkajian terhadap jenis-jenis penggunaan lahan dan agihan perubahan lahan melalui interpretasi citra digital penginderaan jauh dan survei lapangan untuk membuktikan keabsahan data.

\section{Metode Penelitian}

Metode yang digunakan dalam penelitian ini adalah metode penginderaan jauh menggunakan teknik interpretasi citra digital dengan analisis Sistem Informasi Geografis (SIG) terhadap perubahan penggunaan lahan dan observasi lapangan.

\section{Pengumpulan Data}

Data yang digunakan dalam penelitian ini dibagi menjadi dua, yaitu data primer dan data sekunder. Data primer diperoleh dari pengamatan langsung di lapangan berdasarkan hasil interpretasi citra digital. Sedangkan, data sekunder diperoleh dari literatur-literatur yang sesuai dengan topik pembahasan dan data hasil pengolahan citra digital penginderaan jauh.

Populasi merupakan keseluruhan suatu variabel menyangkut masalah yang diteliti. Variabel tersebut dapat berupa orang, kejadian, perilaku atau sesuatu yang akan dilakukan oleh peneliti. 
Populasi adalah kumpulan dari satuan-satuan elementer yang mempunyai karakteristik dasar atau dianggap sama. Karakteristik dasar dicerminkan dalam bentuk ukuran-ukuran tertentu (Yunus, 2010). Populasi dalam penelitian ini berupa keseluruhan unit penggunaan lahan di Desa Mudal, Kecamatan Boyolali, Kabupaten Boyolali dengan populasi sebanyak 422 polygon yang terbagi dalam sembilan klasifikasi penggunaan lahan.

Menurut Yunus, 2010 sampel merupakan kata benda yang mengandung pengertian objekobjek atau bagian dari populasi yang akan diteliti dan dimanfaatkan untuk memperoleh gambaran mengenai karakteristik populasi. Sampel adalah sebagian atau wakil populasi yang diteliti. Di dalam pengambilan sampel, peneliti menggunakan cara atau teknik tertentu, sehingga sampel yang diambil benar-benar representatif. Metode pengambilan sampel yang digunakan oleh peneliti adalah stratified random sampling atau sampel acak bersrata. Stratified random sampling merupakan cara pengambilan sampel dengan terlebih dahulu dilakukan penggolongan populasi menurut ciri geografi tertentu dan setelah digolongkan ditentukan jumlah sampel dengan sistem pemilihan secara acak.

Tabel 1. Diagram Alir Teknik Pengumpulan Data

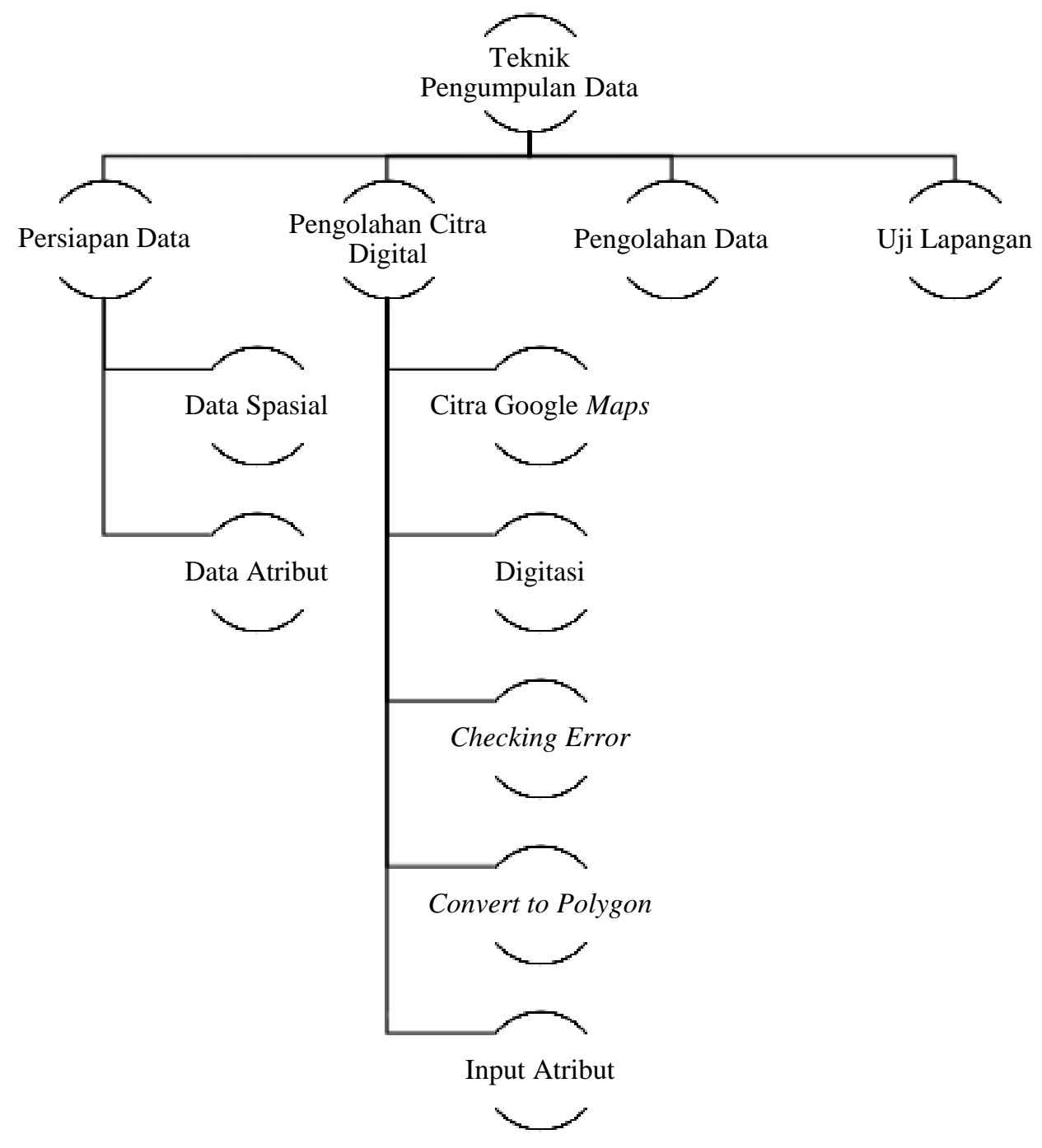

(Sumber: Peneliti, 2019) 
a) Persiapan Data

1. Data Spasial

Data spasial atau yang lebih dikenal dengan data informasi geografi dapat menunjang sistem sebagai upaya dalam menghasilkan informasi tertentu sesuai dengan kebutuhannya. Data spasial yang digunakan dalam penelitian ini adalah data citra google maps Tahun 2015 dengan lokasi berada di Desa Mudal.

2. Data Atribut

Data atribut merupakan data yang berbentuk tulisan maupun angka-angka. Data atribut di antaranya terdiri dari jenis penggunaan lahan dari setiap bangunan. Data tersebut diperoleh melalui proses interpretasi citra di Desa Mudal.

b) Pengolahan Citra Digital

Pemanfaatan citra digital penginderaan jauh telah banyak dilakukan terutama untuk mengidentifikasi perubahan bentuk, luas, ataupun kondisi lainnya dari suatu wilayah. Pengelolaan citra google maps ini terdapat beberapa langkah-langkah, sebagai berikut.

1. Citra google maps yang telah diunduh diimpor ke dalam software ArcGIS.

2. Digitasi dilakukan untuk proses konversi objek geografis dari data raster ke data vektor.

3. Checking error bertujuan untuk mengetahui kesalahan-kesalahan yang harus dibenarkan ketika melakukan digitasi.

4. Convert to polygon merupakan proses berubahnya shapefile line menjadi shapefile polygon.

5. Input atribut dilakukan untuk mengetahui perbedaan penggunaan lahan dari setiap blok.

c) Pengolahan Data

Pengolahan data yang diperoleh dari hasil identifikasi dan interpretasi citra diawali dengan proses penghitungan jumlah seluruh anggota sampel dengan rumus Taro Yaname dan Slovin. Adapun rumus tersebut sebagai berikut.

$$
\begin{array}{ll}
\mathrm{n} & =\text { Jumlah Anggota Sampel } \\
\mathrm{N} & =\text { Jumlah Populasi } \\
\mathrm{d}^{2} & =\text { Presisi }
\end{array}
$$$$
\mathrm{n}=\frac{\mathrm{N}}{\mathrm{N} \cdot \mathrm{d}^{2}+1}
$$

Kemudian, menghitung pengambilan sampel dengan teknik stratified random sampling menggunakan rumus alokasi proportionate. Adapun rumus tersebut sebagai berikut.

$$
n i=\frac{N i}{N} \cdot n
$$

ni = Jumlah Anggota Sampel Menurut Kelas

$\mathrm{Ni}=$ Jumlah Anggota Populasi Menurut Kelas

$\mathrm{N}$ = Jumlah Anggota Populasi Seluruhnya

$\mathrm{n} \quad=$ Jumlah Seluruh Anggota Sampel

Pengolahan data ini dilakukan dengan menggunakan software Microsoft Excel dan langkah-langkahnya sebagai berikut.

1. Export data atribut ke Microsoft Excel,

2. Lakukan pembagian dan penomoran pada sampel,

3. Acak sampel, 
4. Setelah dilakukan pengacakan sampel, input kembali data ke dalam software ArcGIS dengan tujuan untuk mengetahui hasil sampel yang telah teracak.

d) Uji Lapangan

Uji lapangan dilakukan dengan tujuan untuk membandingkan hasil citra yang telah dilakukan interpretasi apakah dalam bidang kajian terdapat perubahan lahan atau tidak. Teknik pengumpulan data dengan observasi digunakan bila penelitian berkenaan dengan perilaku manusia, proses kerja, gejala-gejala alam dan dalam segi proses pelaksanaan pengumpulan datanya dapat dibedakan menjadi participant observation (observasi berperanserta) dan non participant observation. Selanjutnya, dari segi instrumentasi yang digunakan, maka observasi dapat dibedakan menjadi observasi terstruktur dan tidak terstukrur (Notoatmodjo, 2012).

Penelitian ini menggunakan non participant observation yaitu peneliti tidak terlibat langsung dengan aktivitas responden yang sedang diamati, maka observasi non partisipasi, peneliti hanya sebagai pengamat independen, sehingga makna yang terkumpul hanyalah nilai-nilai di balik perilaku yang tampak, yang terucap, dan yang tertulis.

\section{Analisis Data}

Analisis data yang dilakukan adalah dengan uji ketelitian interpretasi citra menggunakan perhitungan matriks konfusi. Matriks konfusi memuat perhitungan ketelitian masing-masing klasifikasi objek dan interpretasi keseluruhan. Selain itu, matriks tersebut memuat perhitungan omisi dan komisi, yaitu perhitungan kesalahan interpretasi, sehingga uji ketelitian tersebut tidak termasuk dalam pengukuran tunggal dan merupakan prosedur uji ketelitian yang valid.

\section{Hasil dan Pembahasan}

Pengolahan data dalam penelitian ini dimulai dari kegiatan interpretasi citra digital dengan menggunakan delapan unsur interpretasi citra yang terdiri dari rona (warna), bentuk, ukuran, tekstur, pola, bayangan, situs, dan asosiasi. Untuk mengukur ketelitian hasil interpretasi citra, maka dilakukan dengan menggunakan teknik survei lapangan dengan mengambil sampel objek penelitian.

Peneliti menguji ketelitian data dengan menggunakan pengamatan langsung atau ground check yang bertujuan untuk mengetahui tingkat ketelitian dari interpretasi citra digital penginderaan jauh. Ground check dilakukan dengan membandingkan hasil dari pengolahan citra google maps dengan objek yang ditemukan di lapangan. Berikut hasil perbedaan peta perubahan penggunaan lahan yang merupakan hasil interpretasi citra dengan peta penggunaan lahan setelah dilakukannya pengamatan di lapangan. 


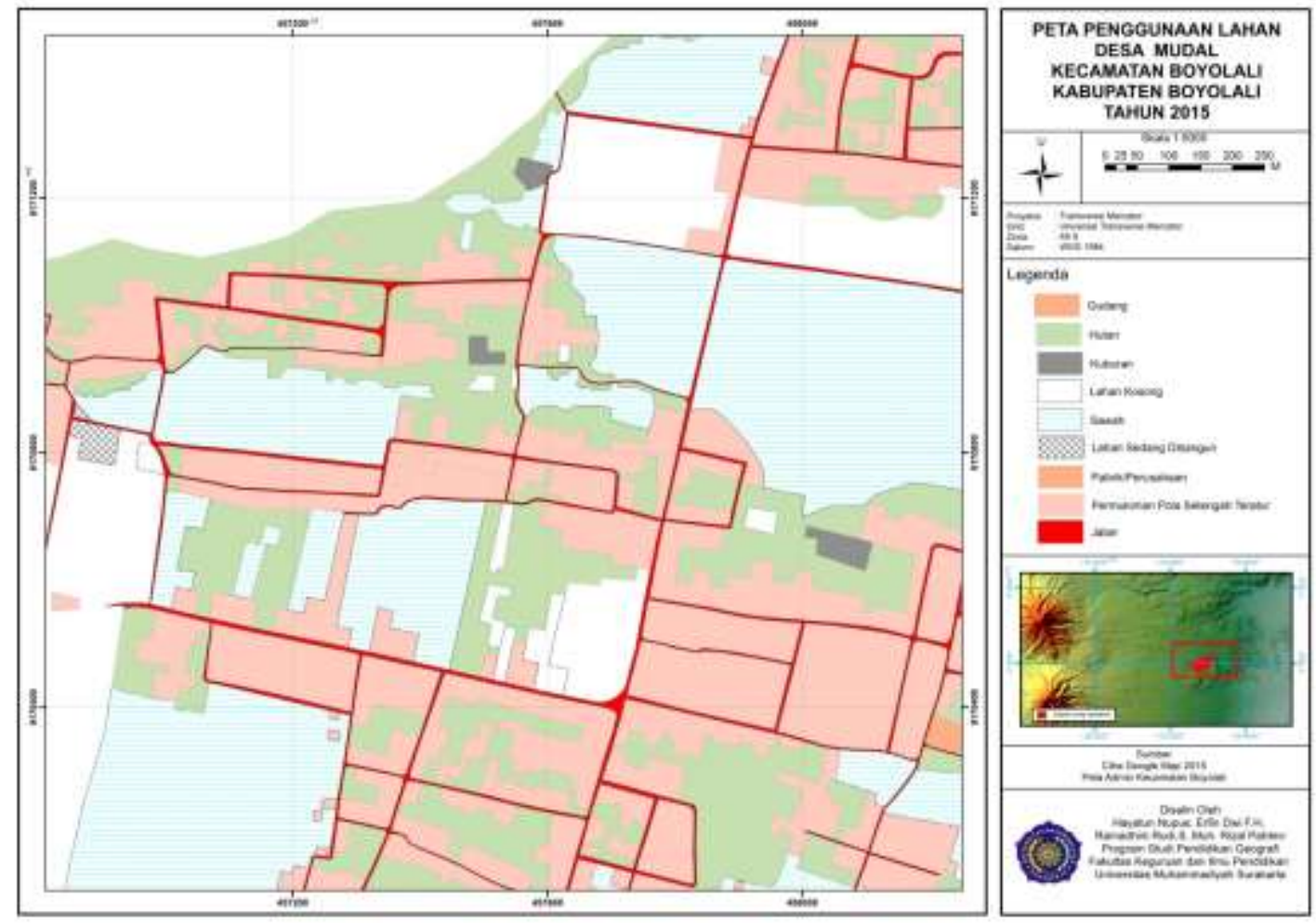

Gambar 1. Hasil Interpretasi Penggunaan Lahan dengan Menggunakan Citra Google Maps Tahun 2015 (Sumber: Peneliti, 2018)
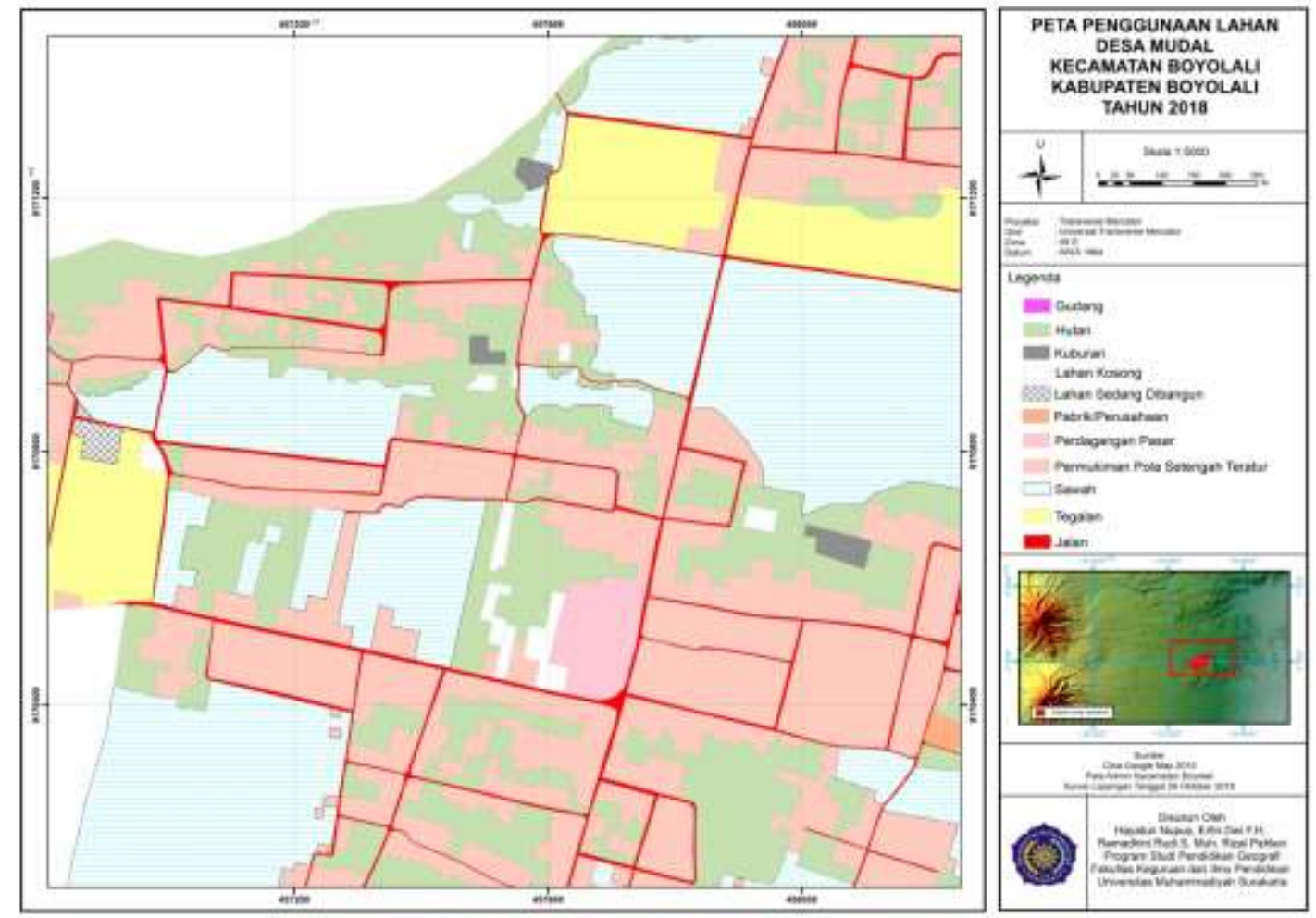

Gambar 2. Hasil Survei Lapangan Perubahan Penggunaan Lahan Tahun 2018 (Sumber: Peneliti, 2018)

Perkembangan wilayah identik dengan lahan terbangun. Lahan terbangun adalah kenampakan di permukaan bumi yang telah mengalami campur tangan manusia dan memiliki 
fungsi tertentu bagi kehidupan manusia, dibatasi dengan kenampakan fisik terbangun seperti rumah, pabrik, dan aspal (Nurwati, 2010). Berdasarkan hasil interpretasi citra google maps ditemukan delapan penggunaan lahan yang terdapat di Desa Mudal yaitu, gudang, hutan, kuburan, lahan kosong, sawah, lahan sedang dibangun, pabrik perusahaan, permukiman pola setengah teratur. Sedangkan, setelah dilakukannya survei lapangan, peneliti menemukan beberapa penggunaan lahan yang tidak ditemukan saat interpretasi, seperti perdagangan pasar dan tegalan. Hal ini menunjukkan pemanfaatan perubahan penggunaan lahan yang terdapat di Desa Mudal yaitu yang awalnya lahan kosong menjadi tegalan dan lahan kosong menjadi perdagangan pasar.

Data hasil klasifikasi dan uji lapangan menunjukkan parameter uji ketelitian dapat diamati masing-masing kategori untuk ketelitiannya yang meliputi ketelitian penghasil, ketelitian pengguna, kesalahan omisi, kesalahan komisi, dan ketelitian keseluruhan. Uji kesepakatan dihitung dengan menggunakan rumus Cohen Kappa Cohen (1960) dengan mengembangkan koefisien untuk mengukur kesepakatan koefisiensi Kappa.

Tabel 2. Confusion Matrix Calculation

\begin{tabular}{|c|c|c|c|c|c|c|c|c|c|c|c|c|}
\hline & & & & Lapangan & & & & & & & & \\
\hline Kelas & Sawah & Hutan & Gudang & $\begin{array}{l}\text { Lahan } \\
\text { Kosong }\end{array}$ & Kebun & $\begin{array}{l}\text { Permukiman } \\
\text { Pola Setengah } \\
\text { Teratur }\end{array}$ & Kuburan & $\begin{array}{c}\text { Pabrik/ } \\
\text { Perusahaan }\end{array}$ & $\begin{array}{l}\text { Perdagangan } \\
\text { Pasar }\end{array}$ & Total & $\begin{array}{c}\text { User } \\
\text { Accurasy }\end{array}$ & Omission \\
\hline Sawah & 21 & 0 & 0 & 0 & 7 & 0 & 0 & 0 & 0 & 28 & 75 & 25 \\
\hline Hutan & 0 & 57 & 0 & 0 & 1 & 0 & 0 & 0 & 0 & 57 & 100 & 2 \\
\hline Gudang & 0 & 0 & 1 & 0 & 0 & 0 & 0 & 0 & 0 & 1 & 100 & 0 \\
\hline Lahan Kosong & 0 & 0 & 0 & 7 & 0 & 0 & 0 & 0 & 0 & 7 & 100 & 0 \\
\hline Kebun & 0 & 0 & 0 & 0 & 0 & 0 & 0 & 0 & 0 & 0 & 0 & 0 \\
\hline Permukiman pola Setengah Teratur & 0 & 0 & 1 & 0 & 0 & 113 & 0 & 0 & 1 & 115 & 98 & 2 \\
\hline Kuburan & 0 & 0 & 0 & 0 & 0 & 0 & 2 & 0 & 0 & 2 & 100 & 0 \\
\hline Pabrik/ Perusahaan & 0 & 0 & 0 & 0 & 0 & 0 & 0 & 2 & 0 & 2 & 100 & 0 \\
\hline Perdagangan Pasar & 0 & 0 & 0 & 0 & 0 & 0 & 0 & 0 & 0 & 0 & 0 & 0 \\
\hline Total & 21 & 57 & 2 & 7 & 8 & 113 & 2 & 2 & 1 & 212 & & \\
\hline Prosedur Akurasi & 100 & 100 & 50 & 100 & 0 & 100 & 100 & 100 & 0 & & & \\
\hline Commision & 0 & 0 & 50 & 0 & 100 & 0 & 0 & 0 & 100 & & & \\
\hline Overall & 203 & & & & & & & & & & & \\
\hline
\end{tabular}

Hasil uji ketelitian ini dapat dibuktikan dengan beberapa perhitungan berikut ini.

1. Overall Accurasy

Overall Accurasy menghitung banyaknya pixel yang terklasifikasi dengan benar pada setiap pixel per kelas.

$$
\begin{gathered}
\text { Overall Accurasy } \%=\frac{j \text { umlah pixel yang terklasifikasi dengan benar }}{\text { jumlah keseluruhan sampel }} \\
=\frac{(21+57+1+7+113+2+2}{212} \\
=203
\end{gathered}
$$

2. Procedur Accurasy

Procedur Accurasy menunjukkan objek dipermukaan bumi yang direpresentasikan pada saat klasifikasi.

$$
\text { Procedur Accurasy }=\frac{\text { jumlah pixel pda kelas tertentu yang benar }}{\text { jumlah keseluruhan kelas tertentu }}
$$


3. Indeks Kappa

$$
\begin{gathered}
K=\frac{212 .(203)-16891}{212^{2}-16891} \\
K=\frac{43036-16891}{44944-16891} \\
K=\frac{26145}{28053} \\
K=0,93
\end{gathered}
$$

Diketahui bahwa tingkat ketelitian hasil dari interpretasi citra google maps penggunaan lahan di Desa Mudal adalah 100\%. Hal ini sudah memenuhi standar, karena tingkat ketelitian telah mencapai 75\%. Dari hasil tersebut dapat diartikan bahwa kualitas data yang diuji sudah memenuhi jumlah sampel yang ada. Nilai Kappa menurut Bhisma Murti (1997), nilai $K>0,75$ menunjukkan kesepakatan sangat baik, bila nilai $K=0,04$ 0,75 menunjukkan kesepakatan baik dan bila nilai $\mathrm{K}<0,40$ menunjukkan kesepakatan lemah. Berdasarkan hasil dari Indeks Kappa, penelitian ini memiliki keeratan kesepakatan atau ketelitian yang sangat kuat.

4. Perbandingan Interpretasi Citra dengan Survei Lapangan

Hasil interpretasi citra google maps dan hasil survei lapangan tidak memiliki perbedaan yang signifikan. Dengan demikian, maka dapat ditarik kesimpulan bahwa citra google maps dapat digunakan sebagai interpretasi perubahan penggunaan lahan.

\section{Kesimpulan}

Citra google maps dapat digunakan untuk mengidentifikasi penggunaan lahan yang kompleks. Dengan menggunakan teknik interpretasi citra penggunaan lahan di Desa Mudal dapat terklasifikasikan dengan rinci. Berdasarkan hasil analisis data dan pembahasan yang telah dikemukakan dapat disimpulkan sebagai berikut.

1. Tingkat ketelitian interpretasi citra google maps untuk objek penggunaan lahan adalah 100\%. Dengan demikian, keseluruhan hasil interpretasi citra google maps dapat diterima, karena telah memenuhi persyaratan batas minimal ketelitian interpretasi data penginderaan jauh.

2. Setelah dibandingkan antara citra google maps pada Tahnu 2015 dengan survei lapangan yang dilakukan Tahun 2018, hasil menunjukkan bahwa tidak mengalami perubahan yang signifikan.

Tindak lanjut bagi penelitian selanjutnya diharapkan dapat melakukan penelitian dengan tingkat keakuratan data yang sangat baik dan dapat digunakan dasar sebagai penelitian yang sejenis dengan melakukan pemetaan perubahan penggunaan lahan di wilayah lain.

\section{Ucapan Terimakasih}

Peneliti mengucapkan terima kasih kepada Program Studi Pendidikan Geografi, Fakultas Keguruan dan Ilmu Pendidikan, Universitas Muhammadiyah Surakarta dan masyarakat Desa Mudal yang telah diizinkan untuk melakukan penelitian di wilayah setempat.

\section{Daftar Rujukan}


D. Nurwati. (2010). Analisis Citra Penginderaan Jauh Multitemporal untuk Mengetahui Trend Lahan Terbangun di Daerah Surakarta dan Sekitarnya. Fakultas Geografi Universitas Gadjah Mada, Yogyakarta. Skripsi.

Notoatmodjo, S. (2012). Metodologi Penelitian Kesehatan. Jakarta: Rineka Cipta.

Ritohardoyo, S. (2013). Penggunaan dan Tata Guna Lahan. Yogyakarta: Penerbit Ombak.

Somantri, Lili. (2016). Pemanfaatan Teknik Penginderaan Jauh untuk Mengidentifikasi Kerentanan dan Risiko Banjir. Jurnal Geografi. Vol. 8, No.2.

Utaya, S. 2008. Pengaruh Perubahan Penggunaan lahan Perumahan terhadap Sifat Biofisik Tanah dan Kapasitas Infiltrasi di Kota Malang. Jurnal, Universitas Negeri Malang, Malang.

Yunus, Hadi Sabari, (2010). Metodologi Penelitian Wilayah Kontemporer. Yogyakarta: Pustaka Pelajar. 